\title{
Breast Milk as the Forgotten Ethical Right in Surrogacy and Suggestions for Its Recognition: Islamic Perspective, Iranian Experience
}

\author{
Nazafarin Ghasemzadeh,, ${ }^{1, *}$ Seyed-Mahdi Salehi, ${ }^{2}$ and Fatemeh Faramarzi-Razini ${ }^{2}$ \\ ${ }^{1}$ Medical Ethics and History of Medicine Research Center, Tehran University of Medical Sciences, Tehran, IR Iran \\ ${ }^{2}$ Jurisprudence and Islamic Law Department, Urmia University, Urmia, IR Iran \\ "Corresponding author: Nazafarin Ghasemzadeh, Medical Ethics and History of Medicine Research Center, 4th level, No.21, 16 Azar Ave, P.O. Box: 1417863181, Tehran, IR Iran. Tel: \\ +98-2188986388; +98-9143438927, E-mail: nghasemzadeh@razi.tums.ac.ir
}

Received 2016 May 31; Revised 2016 December 13; Accepted 2017 March 09.

\begin{abstract}
Background: Humans have made various efforts to overcome infertility since ancient times. One of the modern assisted reproductive techniques is surrogacy which in this way; a woman agrees to become pregnant and carry a baby for another couple and give them the resulting offspring after birth so that they take paternal and maternal responsibility. The content of the contracts between the owner of the uterus and the applying couples is delivery of the baby to the intended couples that is usually determined by indicating the time "immediately after birth" or "as soon as birth" or "upon birth" when the nutritional status of the child by breastfeeding is not determined and even in other articles it has not even been considered. In Iran, according to the articles of the written surrogacy contract, surrogate has to deliver the baby to the intended couples immediately after birth, too. Therefore breastfeeding of newborn infant has been missed in surrogacy agreement.

Objectives: In this study, we have attempted to defend the right to be breast-fed for the child of surrogacy and the right of the breast-feeding for the surrogate mother as rights that make others obligation in Iran. In addition, we propose an altruistic way and the acceptance of two motherly perspectives in surrogacy for the realization of this right.

Methods: This study is a theoretical, review, library and content analysis study. First, a combination of key words such as Surrogacy Act, Ethics, Surrogacy Arrangement, and Breastfeeding was searched in the valid databases. Due to lack of the theme of breastfeeding in surrogacy contracts, in the second part of the study, the importance of breast milk was investigated from the medical and Islamic perspectives by searching keywords in medical database, verses of Quran and valid juridical sources and the related extracted information were categorized and their content was analyzed. Then, the right to breastfeed the baby in surrogacy was examined from the rights perspective and how to exercise this right.

Results: Consideration of the importance of breastfeeding from the medical, Islamic points of view and legal perspective, breastfeeding is recognized as a right of newborn and mother's right or obligation. Surrogacy develops a mother-child relationship and is therefore liable to mother and child benefits. On the other hand, the breastfeeding right is not mentioned explicitly in surrogacy contract and this right has been missed.

Conclusions: It is suggested that in surrogacy both the intended parents and the owner of the womb be provided with the necessary information about the advantages of the breast milk for the child and for the mother at the time of consulting before signing the contract. In addition, the breastfeeding right should be given to the surrogate mother and it should be stated that this right is not considered as the custody right.
\end{abstract}

Keywords: Breastfeeding, Surrogacy Contract, Islamic Perspective

\section{Background}

Family and reproduction are the basic elements of human life and infertility is one of the most challenging situations in human life (1). Humans have made various efforts to overcome infertility since ancient times (2) and one of the successes of the late twentieth century was advances in the field of assisted reproduction (3). These methods, however, appeared in response to the needs of infertile couples. Nonetheless, with their emergence, new challenges have been created in terms of moral, emotional, social and le- gal issues that without responding to these challenges, we cannot willingly use these methods (4).

One of the new methods of assisted reproduction is surrogacy which is rarely used compared to other existing methods that is sometimes considered as the only practical way for solving the problem of infertility in some couples (3). In this way, a woman agrees to become pregnant and carry a baby for another couple and give them the resulting offspring after birth (5-7) so that they take paternal and maternal responsibility. These couples are called com- 
missioning, applicant or intended parents and the woman who carries the embryo is called surrogate mother, mother who gives birth to a baby, alternative in gestational (5) or the owner of the womb or surrogacy (8). Using surrogacy takes place in two major ways, including full surrogacy and partial or traditional surrogacy. In the partial surrogacy, the surrogate mother becomes pregnant through in vitro fertilization by using her ovum/egg and intended father's sperm or donated sperm and has a genetic relationship with the resulting child (3). In full surrogacy, embryo resulting from in vitro fertilization of the sperm and ovum of the intended parents or donated sperm and intended mother's ovum, or intended father's sperm and donated ovum, or donated sperm and donated ovum is transmitted into surrogacy. In this case, the resulting child has no genetic linkage to the surrogate mother $(5,6)$.

The owner of the womb can play her surrogacy role through a commercial contract (earning money from the intended parents) or altruistic contract (noncommercial and without earning money but a reasonable compensation costs related to pregnancy and childbirth $)(2,9)$. One of the articles of the contracts between the owner of the womb and the applicant couple is delivery of the baby to the intended couple that is usually determined by indicating the time "immediately after birth" or "as soon as birth" or "upon birth" or "at birth" (2, 7, 9-14) when the nutritional status of the child by breastfeeding is not determined and even in other articles, this issue has not even been considered. Surrogacy as currently practised in Iran, is allowed based on jurisprudential opinions (fatwa) of the majority Shiite jurists for infertile legal couples, as a treatment for their infertility $(2,9,12,13)$. In Iran, according to the articles of the written surrogacy contract, surrogate has to deliver the baby to the intended couple immediately after birth, too $(2,9)$. Therefore breastfeeding of newborn infant has been missed in surrogacy agreement.

When a baby is born, one of his or her rights will be breastfeeding (15). Today, the revival of this right has been considered more and more by health policy makers at a global level by recognizing the value of breastfeeding, and they attempt to maintain, support, and promote breastfeeding (15). For this purpose, health service providers have a duty and a moral imperative to provide pregnant and newly delivering mothers with the necessary information based on scientific evidence about the benefits of breastfeeding and probable risks of not feeding up with it and encourage them to use breast milk and give them the necessary training on breastfeeding (16). Since the surrogate mothers enjoy especial health services of pregnant women and health group commitment to these women are similar to that of the other pregnant women $(3,17)$, in this review and analytical study, we have attempted to defend the right to be breast-fed for the child of surrogacy and the right of the breast-feeding for the surrogate mother as rights that make others obligation in Iran. In addition, we propose an altruistic way and the acceptance of two motherly perspectives in surrogacy for the realization of this right. In this regard, the current study tries to a) explain the importance of breast milk from the medical and Islamic point of view, b) discuss breastfeeding challenges in surrogacy from ethical perspective, and c) present a solution to it.

\section{Methods}

This study is a philosophical theorizing, review, library and content analysis study. In the first step, our theory (breastfeeding has been missed in surrogacy) created based on the database information, then a combination of key words such as Surrogacy Act, Surrogacy Contract, Ethical issue, Ethics, Surrogacy Arrangement, Breastfeeding, Breastfeeding Rights was searched in INLM, Pubmed, and Google Scholar websites. Then, the obtained information were classified and the contents of laws and obtained agreements from countries including the USA, Australia, England, New Zealand, Canada, India and Iran were studied. Due to lack of the theme of breastfeeding in these contracts, in the second part of the study, the premises and the related propositions have been applied to prove our theory (18). Besides, the premises used to prove the theory issues are related to the importance of breastfeeding in the field of medical, religious, and legal aspects. In this regard, the importance of breast milk was investigated from the medical and Islamic perspectives by searching keywords such as breastfeeding advantages in medical database and searching keywords such as Om, Valedeh, Redaa (suckling), Rade'a (foster), Mortada'a (the child who sucks his/her mother's breast), Morda'eh (foster mother), Leba (the first milk of mother), the child's right, the mother's right, breastfeeding advantages, the obligation and definition of mother in the verses of Quran, respectively and these keywords were also examined in valid juridical sources, commentary and narrative texts and the related extracted information were categorized and their content was analyzed. Content analysis used in this method was of conceptual analysis nature. Breaking down of the elements and finding the relationship among the Qur'anic verses were applied in this method (19). Conceptual as well as Qur'anic analysis were used in the present study in which semantic relationships between words regarding meaning inclusion, synonymy, and semantic opposition were investigated using semantics' principles. Thus, concepts and terms such as synonyms, antonyms, general and specific, major and minor, convergent and divergent, and single-focal and multifocal are differentiated from each other. Thus, valid Qur'anic, 
medical, and legal arguments were used to prove our theory. In addition, the identity of the child in the womb of the surrogate mother to be breastfed is looked at as dilemma; dialectic reasoning is used in solving that (18). Then, the right to breastfeed the baby in surrogacy was examined from the rights perspective and how to exercise this right.

\section{A Glance at the Laws and Contracts of Surrogacy}

Agreement and the relationship between intended parents and the surrogate mother will be applicable when it is considered in a number of legal events (2). That is why many countries try to solve the problems related to surrogacy by providing specific rules and in some cases providing examples of contracts between intended parents and the surrogate mother (9). Similarly, in some countries, such as France, Germany, Sweden, Turkey, Italy, Switzerland, Austria, Finland, Singapore, Slovenia, Viet Nam and Tunisia, the use of surrogacy is forbidden. In some other countries such as the UK, Canada, New Zealand, Japan, the Netherlands, Greece, Denmark and Australia the use of surrogacy is permitted but advertisement and commercial surrogacy is prohibited. However, in some countries such as India, Ukraine and Russia, its commercialization is also permitted. In some countries, the law is silent and there is no law regarding the prohibition or permission to use surrogacy. However, the facts on the ground reveal the implementation of this method $(20,21)$. By looking at the pregnancy alternative rules in a number of states of America, it is evident that there is no discussion regarding breastfeeding. Expressions such as transfer of parental rights and custody of the child to intended father and mother immediately after birth and adoption of child support and custody immediately after birth by father and mother $(22,23)$ and the commitment of the owner of the womb to deliver the baby after birth (24) is used in contracts. Thus, lack of breastfeeding is concluded since immediate delivery of the child prevents breastfeeding (25). This is contrary to the ethical codes of the United States in which the surrogate mother has the right to terminate the contract within a reasonable time after the child's birth, although the justification for this right (termination of the contract) in the full surrogacy is vague and is not clear (26).

In the UK, according to law, surrogacy contract is not an enforceable/ a legally binding contract and the surrogate mother is considered as the child's legal mother and has the maintenance right to keep the child(3)and her consent is required for the transfer of parental rights to the intended one(s) at least 6 weeks after the baby's birth in order to issue a decision $(27,28)$ and the owner of the womb has the right to meet the baby in the hospital (29). Likewise, this contract is not enforceable in Australia and the transfer of parentage should not be less than 28 days and more than 6 months after the child's birth (30). In Russia, the surrogate mother has the maintenance right to keep the child unlike the previous agreements (31). Therefore, it seems that in these countries, despite lack of explicit expression about breastfeeding, this right is reserved for the surrogate mother. There is also no discussion about breastfeeding in New Zealand, but there is a commitment to ethical advice about the rights of surrogate mother (32). In Canada, it is stated that the owner of the womb should be informed all her moral and legal rights (33), while breast milk has not been mentioned and delivery of the baby after birth is used in the contracts. However, in Canada and the USA and most other countries, breastfeeding is recognized as a right and protected by the law and providing the necessary facilities is required to its support (34). In India, the contract is enforceable and the owner of the womb is considered as the mother of the child and intended parents have the right to adopt the child with six weeks delay after delivery and this delay is due to the required mother's consent (35), and it seems that the mother can use this 6-week opportunity.

As it is evident, the breastfeeding right is not mentioned explicitly in none of these laws and contracts. In Iran, surrogacy is being practised, there is no mention of a codified law in terms of surrogacy $(2,9,12,13)$ and also in the stated contracts, breastfeeding and the duty of baby friendly hospitals is not referred to at birth.

\section{The Importance of Breast Milk from a Medical Per- spective}

Scientific evidence clearly shows that breastfeeding makes children and infants less susceptible to middle ear infections, diarrhea and vomiting, atopic dermatitis, type I and type II diabetes, sudden infant death syndrome, children's leukemia (16), obesity and asthma $(15,16)$. Due to having high levels of unsaturated fatty acids, particularly acid arachidonic and high levels of DHA (docosahexaenoic acid) fatty acid, breast milk leads to an increase in IQ, distinguishing power, speech, and memory in children and infants. That is why babies who are breastfed are more alert, more active and more emotional (15). In contrast, children who are fed with alternative milks such as artificial milk are more susceptible to infectious diseases, allergies, disabilities, malnutrition, underweight, and have higher mortality rates (15).

The composition of breast milk in terms of fat, carbohydrates, protein, minerals, salts and various vitamins and variations of these compounds in breastfeeding period are appropriate for the growth and developmental needs of infant and in any weather conditions, it provides adequate 
water for the baby (36). The composition of breast milk of mothers who give birth prematurely is appropriate to the needs of premature infants, the risk of suffering from Necrotizing enterocolitis (NEC) is reduced (15) and is the best nutritional choice for them (37). Also the composition of breast milk varies according to infant's need at the time of diseases, even in cases when the baby suffers from certain diseases such as Cystic fibrosis or Down syndrome from the beginning it is appropriate to his needs (15).

In general, the proportion of the composition of breast milk based on child's need begins from pregnancy period so that the first flow of breast milk that is called colostrum contains a large number of white blood cells, immune factors, antiseptic elements and antibodies amount of which is tens of hundreds of thousands in comparison with the breast milk and it is considered as the child's first dose of vaccination and feeding it to the baby has a very special importance and protects him against infections that he will suddenly face (15).

In addition, breastfeeding plays an important role in mother's health and causes the womb to return to its normal position after delivery (38), the possibility of unusual bleedings, anemia and mortality caused by bleeding are reduced in mother and the mother's weight during the first 6 months of breastfeeding will return to pre-pregnancy weight. It also reduces the risk of breast and ovarian cancer, type II diabetes, postpartum depression $(15,16)$ and osteoporosis in the mother $(15,38)$.

Due to the unmatched and uniqueness of breastfeeding (16) and the role of nutrition with it in providing, maintaining, protecting and improving the health of infancy, childhood, adolescence, young and old, as well as maternal health, the World Alliance for Breastfeeding Action formed a movement to promote breastfeeding $(15,39)$ and stated that the first day of August of each year is the international day of breastfeeding and the first week of this month is the global week of breastfeeding so that the values of breastfeeding could be introduced to the world and all the people in the world honor it (15). In this regard, the world health organization that has considered breastfeeding as human rights, along with UNICEF has developed "global strategy for feeding infants and young children" and emphasized exclusive breastfeeding for 6 months and the constant breastfeeding for 2 years and stressed supporting mothers in the family, workplace and community (15) and requested the launch of baby-friendly hospitals. Iran is also among the countries that have supported this policy and has implemented them in the country (15). All children and pregnant mothers are subject to breastfeeding support policy and surrogate mothers and the resulting child should be supported within the framework of the aforementioned policies for breastfeeding and take advan- tage of these services.

\section{The Importance of Breast Milk in Quran}

The Holy Qur'an discusses pregnancy, breastfeeding and its related issues in four verses including verse 233 of Surah Baqarah, verse 6 of Surah Talaq, verse 15 of Surah Ahqaf and verse 14 of Surah Luqman (40) among which verse 233 of Surah Baqarah is the most important verse in breast milk and is known as Erda' (suckling) verse (41).

In verse 233 of Surah Baqarah, Allah states that:

"Mothers shall suckle their children for two whole years; (that is) for those who wish to complete the suckling. The duty of feeding and clothing nursing mothers in a seemly manner is upon the father of the child. No one should be charged beyond his capacity. A mother should not be made to suffer because of her child, nor should he to whom the child is born (be made to suffer) because of his child. And on the (father's) heir is incumbent the like of that (which was incumbent on the father). If they want to wean the child on mutual consent and (after) consultation, it is no sin for them; and if ye wish to give your children out to nurse, it is no sin for you, provided that ye pay what is due from you in kindness. Observe your duty to Allah, and know that Allah is Seer of what ye do (42)."

This verse contains several issues that are respectively as follows: two complete years of breastfeeding children, financing divorced mothers in breastfeeding period, the appropriateness of obligations with human's capabilities, prohibition of father from making trouble to the mother, prohibition of mother from making trouble to the father and prohibition of both of them from making trouble to the child, the obligations of father's heir in financing the mother, permission of weaning by consultation and the consent of parents, the permission to give the child to a wet nurse by taking into consideration her financial rights, the necessity to observe piety and God being aware of human beings' deeds (43) which seems that it is due to the importance of breastfeeding issue.

This verse which is about the decree of mothers' breastfeeding, begins with the word "Al-waledat" (mothers) that differs from the word "ommahat" (mothers) because "om" refers to mediated mothers, grandmothers $(44,45)$ and everyone who is at the mothers' place, however, waledah (mother) means mother who has given birth to a child (15) and perhaps the use of the word (waledah) is one of the wonderful points in Holy Quran that includes women receiving embryos and the owners of surrogacy and involves breastfeeding of infants with their borrowed milk, although they are not considered as the child's real mother (41). Moreover, the use of "al" in the word that is plural 
itself means generalizability of the decree to the majority under that issue and includes specifically everyone that "waledeh" applies to them (41) in fact, the plural leading to A and L implies the commonality that God does not bring qualifiers after it so that the verse could be referred to a specific group of mothers (43) and the word "waledat" itself in its literal meaning has a general conceptual meaning which includes all mothers whether they have husbands or they are separated from their husbands $(43,44$, $46,47)$. Of course, some scholars state that since this verse comes after the verses related to the divorced women, the breastfeeding decree of this verse is related to the divorced women, however, the word wa (and) before wāledāt that is considered as both turning and an appeal demonstrates that the verse in terms of juridical decree states a new decree entitled Erda' in comparison with the previous verse, however, it refers to the previous verse (41). The use of the verb "yorde'na" after the word waledat suggests sucking milk from the breast of mother (41) and since waledat give birth to their children, they breastfeed them as a result of instinctive and natural affection (45) so it seems that the audience of the verse is about the breastfeeding decree of all the mothers who give birth to the children.

"Yorde'na" is apparently in the present tense, but in fact it is "command and drafting or imperative" $(45,46)$ meaning that "mothers must breastfeed their children" (46-49). A group of commentators consider it as an emphatic imperative (48) and other groups of commentators consider it as a recommended imperative (46). Moreover, the beginning of the sentence as a nominal sentence is unlike the Arab tradition (basically the sentences start as a verbal sentence) is also indicative of emphasis (41). Then the word "awladahonna" (their children) was used, this word is attributed to mothers and it mentions that the child belongs to the mother (44) and by using the word "honna" (they for female) it leads to incitement of moral conscience of mothers to their children so as to create a more psychological effect in doing maternal task (41) and states that mothers must breastfeed their children (43). On the other hand, there is no doubt that the verb "yorde'na" in verse could not be a statement meaning that "mothers are breastfeeding their children two complete years" because there are mothers who do not do this task, so such news will not always be true and since a lie is not valid in the word of God, therefore, the purpose of using this word and as a result the purpose of using this sentence "alwaledat yarde'na awladahonna" has another meaning (48) that in interpretive and jurisprudence sources, three different opinions have been proposed for the meaning of this sentence (43):

1) The necessity of breastfeeding: Since the informative statement in addition to the meaning of news can mean hope and demand $(46,47)$, in this case the verb yorde'na means necessity and the emphatic imperative and demanding duty and action that mothers must breastfeed their children for two complete years $(43,48)$, particularly in certain circumstances that the child only feeds on mother's breast or a wet nurse cannot be found or the father is not capable of financing a wet nurse, breastfeeding children for two complete years by mothers will be a necessary action (49).

2) Recommendation of breastfeeding: If the informative statement implies hope and there is no contrast, it is indicative of necessity, whereas in this verse in other parts of it sentences such as "leman arada an yotemma ar reda'a", "ala al-mawlude lahu rezqahonna wa keswatahonna...", "latodarra waledatan be waladeha" (it is forbidden to cause to sustain a loss to a mother on behalf of her child, and "wa en aradtom an tastarde'u" (if you want to employ a fostermother) state a non-obligatory evidence, while there is an external evidence such as the absence of coercion of mothers to breastfeed that leads to a recommendation of breastfeeding (43), and according to the fact that breastfeeding happens when the father wants (48), therefore the decree in the verse is a kind of recommendation (46) which is used to mean that breastfeeding is mother's right and it cannot be taken from the mother or it is also used to indicate the priority of the mother in breastfeeding baby to other women $(43,44)$.

3) The priority of the mother in breastfeeding: breastfeeding for two years is the mother's duty and this right must be respected by the father and the father should not take the child from the mother and not give the child to another woman, unless the mother asks for more money than others for breast milking $(43,46,49)$.

After breastfeeding decree, the pious legislator refers to its duration by using the word "hawlayn" which states that the duration of breastfeeding is two complete years and by using the adjective 'full' rejects tolerance in two years and asks mothers to breastfeed their children for two complete years (43). The pious legislator has used the word "hawl" instead of "sanah" which is more common among Arabs so that it could be appropriate from a timer perspective for change, breast-fed baby's weakness, and also fulfillment of momentary maternal duty (43) and hawlayne kamelayn shows that breastfeeding is effective developmentally to infrastructure children's physical and mental health for two complete years (41) and in verse 14 of Surah Luqman it has also been emphasized (43).

After the announcement of breastfeeding duration with the statement "leman arada an yotemma ar redā'a" the decree is related to those who wish to complete breastfeeding period (43). A group of commentators expressed the reason to complete breastfeeding, according to verse 15 of Surah Ahqaf which states that the duration of carrying the 
baby and breastfeeding is 30 months (43) and the required time for breastfeeding of mature infants is 21 months and the required time for breastfeeding of a 6 month premature infant is 24 months to compensate for the shortcomings of short-term carrying period by completing breastfeeding period (50) therefore, according to the aforementioned verse and this verse the duration of less than 21 months in breastfeeding is considered cruelty to a child (41) and 21 months is obligatory and from 21 months to 24 months is recommended (43). In fact, the audience of this verse "leman arada an yotemma ar reda' a" can be both the father and the mother so that they notice that the child must be breastfed for two years, and even in a dispute between father and mother or separation of parents, the father should not separate the child from the mother (43), and he should not take the two year-breastfeeding right from the mother (44). Also, in the next sentences it has been referred to the rule of "no harming" by using the verb "latadaru" based on the fact that the father and the mother should not harm each other and the child by taking the child from the mother and opposition with mother's breastfeeding or the divorced mother by asking for more money to breastfeed the child (43-46, 49, 51, 52) and by using the word "la" in "latadaru" in the mode of Mofa'ele (participatory), all harms have been forbidden (44), because the harm from the mother is intentional while the harm to the baby is forcible (41). Hence, quitting breastfeeding by the mother is cruelty to the child which is rationally obscene and religiously prohibited (41).

In this verse the expenditure of divorced woman in the breastfeeding days is the father's and the his heir's responsibility which also implies that breastfeeding is obligatory on women because if breastfeeding was something desirable, it was not necessary for the father to provide its costs (43), especially by using the word "mawlude lah" the duty of financing the mother in breastfeeding period is the responsibility of the father according to the legislative decree (44) which is to the known and affordable extent (43).

After mentioning the mother's right and the child's right by stating the sentence "faen arada fesala" (if they want to stop sucking) it explains the weaning procedure that should be according to the father's and mother's compromise, agreement, and consultation with each other (41, 43) and consultation with professionals such as physicians (50). Since fesal is based on two proviso of compromise and consultation which includes the woman's consent, therefore, breastfeeding child in the first two years of life is the mother's right and if the mother does not ask for more money, the father will not have the right to separate the child from the mother till the completion of the breastfeeding period. According to Allameh Tabatabai, the use of the word "fesal" is the evidence of non-obligatory custody and of non-obligatory woman's breastfeeding but they are the rights that woman can use or give up (44). Some commentators also suggest that the word fesal indicates being discharged (not giving up), that is, if the mother becomes sick during breastfeeding or hardship situations arise, in that case they can use alternative nutrition and preferably take a wet nurse by consulting with experts and knowing the parties' consent which is a rational process (41).

The verse ends with the expression "wa taqwa... wa a'lamu an ..." which represents emphasis and simultaneously it represents a threat to show the importance of the aforementioned issue in the verse that is the very breastfeeding issue, which implies an obligation (41).

What is obtained from the content of the verse based on the valid interpretive sources as described above implies that according to some jurists (unpopular theory) breastfeeding is an affair that is the duty of all mothers (birth mothers) and its necessity is not a reason to force mothers to do this affair, as in the rest of the acts of coercion it is not permissible to force somebody to do an obligatory act and it is important that people voluntarily perform their duties. On the other hand, some other jurists (popular theory) believe that breastfeeding is not a necessary affair and it is recommended; this is a sign of mother's and the child's right in breastfeeding and both groups believe in mother's priority for breastfeeding the child (43).

Since surrogacy and the resulting baby can take advantage of the content of this verse based on having the right to breastfeed, completion of breastfeeding period (less than 21 months is cruelty to the child), no harm from the mother and the father to the child, providing the mother's expenditure during breastfeeding period by the father or his heirs, priority of mother in breastfeeding the child, decision to weaning the child by the consent and the consultation of the parents, but the present situation in our country (Iran) is not clear in these cases.

\section{The Importance of Breast Milk in Juridical and Nar- rative Texts}

There are several narratives (rewayat) from the infallible Imams which emphasize the use of breast milk and its importance (43) as Imam Ali has said "no milk is more blessing for a child than his or her mother's milk" (5357). This narrative is mentioned in many books (Kafi, Man La Yahdarahol Faqih, Tahdhibol Ahkam, Masalekol Afham wa Wasael osh Shi'a) which is indicative of its validity and importance. Also, the Prophet described breast milk as: "no milk is better for a child than his or her mother's milk" (58).

The value of feeding with breast milk also attracted the attention of jurists in juridical texts and often the importance of breast milk is emphasized by expressing nar- 
ratives and sentences with themes that the best milk for the baby is his/her mother's milk (59-63) since it is more compatible with the nature of the child and it is the same food that the child was fed in his mother's womb $(64,65)$ and it is emphasized that the mother must give her child colostrum that is the first flow of milk (65).

Aljabay Al-Ameli Zaynaddin (known as First Martyr) states in Loma'a that giving colostrum is obligatory and giving milk to a child during breastfeeding period is recommended and the mother can receive a wage from the father regarding both of the situations mentioned above or she can withdraw from the child's property. Therefore, he believed in the mother's priority in breastfeeding the child with receiving a wage equal to others (66) and also he believed in mother's competency in taking the custody of the child during breastfeeding (66). In Alrowda Albahiyya, Mohammad bin Jamaluddin (known as Second Martyr) has argued that the child would not be alive without colostrum, giving colostrum to the baby is obligatory and getting a wage is permissible and he believed that it is an integration of the two rights (the child's right to eat colostrum and the mother's right to get paid) (67).

Giving colostrum to the baby is important to the extent that some of the great Islamic jurists believe that a child's life often depends on eating it $(56,67,68)$ and they attributed the child's physical strength to that (65) and they adjudged that if a woman deserved vengeance or stoning for committing a crime or a criminal act, the execution must be delayed so that she can give her baby colostrum (43) even if the pregnancy occurred after a crime and also if a wet nurse is not found for the child, the breastfeeding duration should be completed before the nemesis could be performed (63) also the jurists without any dispute in terms of the punishment for adultery in pregnant women have stated that the punishment will not be performed regarding the pregnant woman so that she could give birth to her baby and also she is not stoned after giving birth so that she could feed the child with colostrum that the child's strength is dependent on it and if the child ate colostrum, and there is no one to give him milk and take the responsibility of the child's custody, the stoning will not be performed because in stoning of the woman lies the child's death (69-72) that is due to the observance of the child's right regarding colostrum (73).

Another issue that jurists agree upon is the priority of mother in breastfeeding since in Sharaye'ol-Islam fi Masael el-Halal wa Al-Haram it is referred to the recommendation of mothers' breastfeeding their child and the priority of the mother in breastfeeding (74) because breast milk is consistent with the child's body. In fact, the origin of the breast milk is the very same blood that the child (fetus) fed during the carrying period which took the form of milk af- ter birth and for this reason the structure of this milk is close to the nature of the child more than any other material (56).

What is implied from the juridical texts is that mother's milk (the mother is often mentioned by using the word "om") is blessed and unique, its formation has started from the carrying period and it is consistent with the nature and variable needs of a child and the mother's milk has priority to the milk of other women. Also, the first flow of milk (colostrum) has a vital role in child health to the extent that some jurists have made it obligatory to the mother to feed it to the baby. Generally speaking, if breastfeeding the child is not an obligatory duty of the mother, at least, it is something desirable that is indicative of the breastfeeding right for the baby and the mother.

\section{The Importance of Breast Milk from a Legal Perspec- tive}

Globally, in Principle 4 of the universal declaration of child's rights, the child's proper nutrition is considered as one of his/her rights (75) and according to the Article 24 of the convention on the child's rights, the states supporting the convention (Iran is also among them) have been asked to make aware all segments of the society, especially parents of the breastfeeding by necessary trainings and make these trainings available to all members of the community and support these trainings (76).

Also, in the rules and regulations of the Islamic Republic of Iran in accordance with article 1176 of the Civil Code which provides that "mothers do not have to give milk to their children unless the child's nutrition is not possible other than breast milk" it can be seen that breastfeeding is not generally the mother's obligation except in certain cases (77).

On the other hand, according to articles 437 and 443 of Retribution Book of Islamic Penal Code of Iran, a delay is required in implementing capital or member retribution of pregnant or breast-feeding mother if there is possibility of damage to normal course of carrying or to newly born baby until the removal of the threat (78).

In addition, in Article 1046 of the Iran Civil Law, foster relationship due to the milk of a woman is subject to the conditions stated in the same article and it is declared as the relative affinity (77) indicating the importance and value of breast milk. On the other hand, the law of promoting the breastfeeding and supporting pregnant women during lactation was approved by the Iranian Parliament in 1995 in order to support lactation that is expressed in article 3 of its additional note, supporting lactating women 
by increasing maternity leave, daily use of a time off without deduction of paid leave and providing job security to lactating mothers (79). Moreover, the health care system has developed and has stated a guideline "start feeding by mother's milk within the first hour of life" in order to preserve, support and promote breastfeeding (80).

It is derived from the existing laws that breastfeeding is not the mother's duty, but breastfeeding is one of the mother's and the child's rights that is somehow implicit in the custody of the child.

\section{Whose Right is to Breastfeed the Child in Surrogacy?}

According to jurists' famous opinion, breastfeeding the child is the mother's right and she has the priority to others. Since in surrogacy there is disagreement in attributing the title of the mother to either the owner of the womb or the owner of the ovum or both of them, therefore, the owner of this right (breastfeeding) is also faced with challenges that can be proposed in the form of three assumptions:

1) The first assumption: Based on a conventional perspective that assumes the child to be the offspring of the owner of sperm $(9,81)$ and in accordance with the verse 7 of Surah Tariq which states that the human creation is because of jumping water from the loin of the father, and the breast of the mother (40). Also, the verse 54 of Surah Furqan and verse 2 of Surah Insan express that the human creation and lineage is the result of a drop of sperm (82) and describe the role of ovum just like the father's sperm in the first stage of creation, evolution and formation of the child's characteristics so the female owner of the ovum will be considered as the mother $(9,81)$, in this case, breastfeeding right and the priority in breastfeeding revert to her (the owner of the ovum).

What if this mother did not pass the pregnancy period so that milk could be formed in her body, therefore, she cannot feed the child with the pregnancy milk (Milk that has been produced during pregnancy)? Based on today's medical knowledge, the milk can be produced in this woman's body by using medication-induced secretion of milk so that she could also manage to breastfeed (83), although she will mainly need to use subsidiary milk (84). However, this milk which is produced under the inducement from medication does not have a uterine source and it is not of the same blood and food ingredients that have developed the fabric of the child, and it is not in accordance with the child's body changes and it lacks the first flow of milk (colostrum with its own compositions). On the other hand, since it is not the pregnancy milk it cannot even lead to a foster relationship (milk kinship - reda'a) and milk-suckling mahram (unmarriageable kin) (56).
2) The second assumption: on the basis of the conventional (urf'am) perspective that assumes the birth giver as the mother and according to the Quranic verses:

-Verse 2 of Surah Mujadila is related to zihar (when a man pronounces that his wife is like the back of his mother to him - intending by it to divorce her) expresses that their mothers are only those who gave birth to them $(9,40)$. Verse 22 of Surah Maryam specifies that Maryam (peace be upon her) is the mother of Jesus because she was pregnant and gave birth to Jesus, whether her ovum had a role in the creation of Jesus or not (40).

- In verses 12 to 14 of Surah Mōmenun, it becomes clear that the term "qarar" refers to the women's womb in which the sperm is placed and the word "makin" is described as the adjective of the womb and the womb keeps and maintains the sperm from corruption (44).

- Verse 23 of Surah Nisā states that mothers are women to whom human birth leads and descent of humans is connected to them through birth (40).

- Verse 6 of Surah Zummar, verse 32 of Surah Najm, verse 78 of Surah $\mathrm{Nahl}(40,44)$, according to the legislator's perspective in Article 21 of the constitution of the Islamic Republic of Iran which emphasizes supporting mothers, particularly during pregnancy and Article 19 of the Civil Registration Law in Iran regarding issuing the birth certificate and document in which the birth certificate is issued in the name of the birth mother and the articles 1158,1159 and 1160 of the Iranian civil code define a mother as a woman from whom a baby is born by the delivery event (85) and also therapeutic abortion article allows therapeutic abortion under necessary conditions when the mother's life is at stake (86).

If we consider the owner of the womb as the real mother of the child, in this case the breastfeeding right is going to be attributed to her and she has priority. Another kind of evidence can be expressed in support of this view as follows:

- Verse 15 of Surah Ahqaf recommends the man to goodness and kindness towards parents and suggests that the criteria for this decree are the mother's discomfort during pregnancy, childbirth and breastfeeding, in fact, by mentioning these criteria it attempts to stimulate human's emotions and mercy (44) because the mother's hardest conditions are carrying and breastfeeding (50). And also verse 14 of Surah Luqman is related to thanking God and parents and it attempts to invite people to appreciate their parents, especially their mother by mentioning the hardships of pregnancy and of breastfeeding (44). Both verses state the criterion of gratitude towards the mother is related to the difficult stages of fetal development in which the fetus has been grown by mother's sap, and disturbed the mother's rest and relaxation, and the mother hardly 
gave birth to the child and then compensated the deficiencies of carrying in breastfeeding period (44) so pregnancy, childbirth and lactation processes are considered together.

-All the stages of the development of fetus (lacking soul and having a human soul) have occurred in alternative pregnancy in surrogacy that has provided food exchanges between the surrogate mother and the embryo and it is the primer of the process of milk formation (87). In fact, the resulting milk in the surrogate mother is the carrying milk and its origin is the same blood that the child fed during the fetal period and it is suitable with the child's needs (56), so if the resulting child from the surrogacy is premature or cannot feed with the milk other than the mother's milk, the milk of this mother (the surrogate mother) is important to him (15), although some jurists do not consider this milk as the mother milk (88) and based on the opinion of some jurists, since this milk is not the fahl milk (the milk related to surrogate mother's husband) it does not lead to the milk-suckling mahram and foster relationship (89).

- Based on the causal relationship, the child's birth is the cause of being mother and if they take the baby from the woman who gave birth to the baby and prevent the woman from giving milk to the baby this is the result of human selfishness that wants to end this causality relationship and disrupt this order of nature that exists even in animals and this is contrary to the public morals because this milk is necessary for the health of the woman who owns the womb to return back to prenatal and it is also essential for the growth and the development of the infant (90).

According to the above reasons and based on the fact that the pregnancy in woman creates the rights for her including the alimony right even in irrevocable divorce, no abortion right, lack of punishment and nemesis of the pregnant woman and delay in the punishment of the mother due to maintaining the health of the embryo (72) it seems that breastfeeding right in the surrogate mother is the right that is prior to the other mentioned rights and attaching the breastfeeding right to the surrogate mother is more practical.

3) The third assumption: Based on the conventional perspective that considers both the owner of the ovum and the owner of the womb to be the mother $(9,81)$ we consider the child to have two mothers then the breastfeeding right belongs to both of them, therefore, the breastfeeding right can be assigned to the mother who owns the womb whose milk is the continuation of pregnancy regarding that the breastfeeding right does not necessarily accompany the custody right (43). Therefore, we can assign breastfeeding right to the surrogate mother besides assigning the custody right to the mother who owns the ovum. The possibility of this affair is easier in altruistic surrogacy. We can include breastfeeding fees to the mother who owns the womb in both types of surrogacy (altruistic and commercial) and if she asks for more money than others, we can prevent her from breastfeeding the child.

\section{Discussion}

Based on the autonomy principle, every pregnant woman has the right during pregnancy and after delivery to take advantage of the necessary information about the benefits of breastfeeding for her own health and her child's health so that she could make informed decisions about breastfeeding. Providing this information is one of the important tasks of health service providers (91). Since surrogacy declares her readiness to pregnancy based on agreement or surrogacy contract, she must receive the necessary information concerning the benefits of breastfeeding and its importance to the child's and the mother's health at the time of consultation prior to signing the contract so that she could make informed decisions about the surrogacy process and the breastfeeding right. It is also worthy to mention this right in the contract.

Taking into consideration the aforementioned assumption, can the surrogate mother ignore the breastfeeding right at the time of signing the contract?

- Based on the jurists' unpopular opinion that consider the breastfeeding to be the mother's right and obligation, the mother cannot destroy her religious duty with contract and according to the popular view that considers breastfeeding to be the mother's right and a recommended deed, refusing the implementation of this right and of this recommended act can be considered contrary to public morals as well (43).

- Based on Esqat Ma Lamyajeb, first of all, a right should be approved so that it could be avoided (92), since in signing the contract of surrogacy, the breastfeeding right is not created yet, therefore, surrogate mother cannot avoid it and she should wait until after delivery to take action regarding avoiding or implementing this right.

-According to the Ladarar (nonmaleficence) rule which has been emphasized in verse 233 of Surah Baqarah, avoiding this right hurts the mother, the father and the child (42).

- According to the beneficence principle, breastfeeding holds significant advantages for the mother, the child and the society and its ignorance is against the rational interests.

- According to the justice principle, the surrogate is a pregnant woman who has pregnancy rights and the resulting baby has his/her natural rights and avoiding this right is a kind of cruelty to the child and it is against the nature. 
- Since breastfeeding is one of the natural, innate and takwini (genetic) rights, and it is known as a "haqq" in Iranian society and haqq is a subject whose failure to implement endangers public order, so its avoidance is not possible. In cases when feeding the infant is dependent on the surrogate mother's milk, surrogacy contract is in conflict with the infant's right (9) and it is inconsistent with the second part of the Article 1176 of the Iranian civil code (9), especially with the issue of the dependence of the feeding of the resulting infant from the surrogacy to breast milk is determined after childbirth. Therefore, avoiding this right beforehand is not feasible.

Therefore, based on the aforementioned reasons, refusing the implementation of this right in signing surrogacy contract is against public morals and against global attempts and according to the Article 975 of Iranian civil code which states that the content of the contract should not be against public morals (77), it seems that the surrogacy contract will not have the necessary legitimacy.

Even after the child's birth, ignoring this right is contrary to the natural order especially in the case of colostrum that the prevailing view states the obligation of giving it and in cases that the baby is premature it is crucial to the baby's health.

Perhaps the only disadvantage of implementing the breastfeeding right in surrogate mother is the likelihood of more dependency and emotional bond between the baby and the surrogate mother, this harm can be decreased by accepting the view of having two mothers and altruistic type of contracts (as it was a tradition from the past to take a wet nurse) or indirect breastfeeding could be used (without bonding) and expressed breast milk could be given to the baby.

After accepting implementation of breastfeeding right in surrogate mother, the next issue is the duration of breastfeeding that less than 21 months is cruelty to the child, however, its reduction is possible with proviso of parent's consent and consultation with experts. Another issue is the wage of the surrogate mother in breastfeeding period that must be agreed upon but if the surrogate mother asks for more money than other women, this right can be taken away from her.

\section{Conclusion}

Fourteen centuries ago, in Islamic religion, feeding the baby with the breast milk has been recognized as one of the rights of the child. In Quran and narratives, this right has been considered in detail and its various dimensions have been discussed in juridical texts. Today, protection, support, and promotion of breastfeeding are part of global efforts and they are emphasized in the Convention on the Rights of the Child. Unjustified prohibition of child from the breast milk is an abuse against the child and the mother. In surrogacy, the natural order is the production of milk for the resulting child and this is contrary to the nature to ignore the produced milk.

It is suggested that in surrogacy both the intended parents and the owner of the womb be provided with the necessary information about the advantages of the breast milk for the child and for the mother at the time of consulting before signing the contract. In addition, the breastfeeding right should be given to the surrogate mother and it should be stated that this right is not considered as the custody right. Moreover, colostrum should be given to the child after birth and in terms of continued breastfeeding the mutual consent of the intended parents and the surrogate mother should be considered.

On the other hand, if we consider breastfeeding as the right of the owner of the ovum, then the medical group should attempt to ensure that this mother (the owner of the ovum) could also manage to breastfeed by using scientific and medical facilities. In this regard, it is suggested that empirical research studies be conducted on the benefits and relative differing effects of the milk of the surrogate mother and the milk of the owner of the ovum on the future well-being of the child and both mothers.

\section{Acknowledgments}

The authors wish to extend their appreciation to Dr. Kiarash Aramesh for his insightful comments.

\section{References}

1. Chatzinikolaou N. The ethics of assisted reproduction. J Reprod Immunol. 2010;85(1):3-8. doi: 10.1016/j.jri.2010.02.001.

2. Asef $\mathrm{H}$, Roshan M. A comparative study of jurisprudence and legal contract of surrogacy. Tehran: Majd publications; 2009.

3. English V, Romano-Critchley G, Sheather J, Sommerville A. Medical ethics today: The BMA's Handbook of Ethics and Law. London: BMJ Publishing Group; 2004.

4. Asghari F. Ethical issues in surrogate motherhood. J Reprod Infertil. 2008;9(1):30-35.

5. Aramesh K. In: Medical, legal, Islamic Jurisprudential, EthicalPhilosophical, Sociological and Psychological Aspects of Surrogacy. Aramesh K, editor. Tehran: Samt Publications; 2007. Ethical assessment of monetary relationship in surrogacy.

6. Akhundi MM, Behjati Ardakani Z. In: Medical, Legal, Islamic Jurisprudential, Ethical-Philosophical, Sociological and Psychological Aspects of Surrogacy. Akhundi MM, Behjati Ardakani Z, editors. Tehran: Samt Publications; 2007. Surrogacy, definition, types and necessity of its use in infertility treatment.

7. Nosarka S, Kruger TF. Surrogate motherhood. S Afr Med J. 2005;95(12):942-944, 946. [PubMed:16465353].

8. Sachedina A. Islamic biomedical ethics: principles and application. Oxford University Press; 2009. 
9. Nayebzadeh A. Islamic Law and Foreign Legal Systems. Tehran: Majd Publications; 2001. Legal aspects of the newest reproductive methods: surrogacy - egg/embryos donation: A comparative study in the law of Iran.

10. Spitz E. On the Use of Birth Surrogates. Responsa of the CJLS 19912000: The Committee on Jewish Law and Standards of the Conservative Movement. New York: The Rabbinical Assembly; 2000.

11. Boers P. Surrogacy arrangements: The Patchwork legal landscape. Nicholes Family Lawyers 2016. Available from: http://nicholeslaw. com.au/wp-content/uploads/2014/07/Surrogacy-Patchwork.pdf.

12. Akhondi MM, Ardekani ZB. Surrogacy and the necessity for its application in infertility treatment. J Reprod Infertil. 2008;9(1):7-13.

13. Rahimi HA. Civil responsibility in surrogacy. $J$ Reprod infertil. $2008 ; 9(2)$.

14. Meinke SA. Surrogate motherhood: ethical and legal issues. National Reference Center for Bioethics Literature, Kennedy Institute of Ethics, Georgetown University; 1990.

15. Society for the promotion of breastfeeding under the auspices of healthy deputy of the Ministry of Health and Medical Education with the cooperation of UNICEF in Iran . Educational pack for breastfeeding. Tehran: UNICEF Office in Iran; 2009.

16. Miracle DJ, Fredland V. Provider encouragement of breastfeeding: efficacy and ethics. J Midwifery Womens Health. 2007;52(6):545-8. doi: 10.1016/j.jmwh.2007.08.013. [PubMed: 17983990].

17. Committee on Ethics . ACOG committee opinion number 397. Obstet Gynecol. 2008;111(1):465-70.

18. Baggini J, Fosl PS. The Philosopher's Toolkit: A compendium of philosophical concepts and methods. John Wiley \& Sons; 2011

19. Rafipoor F. Special research techniques in social sciences. Tehran: Enteshar publications; 2003.

20. Biopolicywiki . Surrogacy 2016. Available from: http://www. biopolicywiki.org/index.php?title=Surrogacy\#searchInput.

21. More Countries surrogacy laws . Indian surrogacy laws surrogacy India 2010. Available from: http://www.kaylegalsurrogacy.com/morecountries.html.

22. Fertility SOURCE Companies. The Donor SOURCE and the Surrogacy SOURCE). Sample GS Contract 2016. Available from: http://www. allaboutsurrogacy.com/sample_contracts/GScontract1.htm.

23. Findlaw . Checklist: Surrogacy contract 2016. Available from: http //family.findlaw.com/surrogacy-artificial-conception/checklistsurrogacy-contract.html.

24. Surromomsonline . Sample gestational surrogacy contract 2016 Available from: http://www.surromomsonline.com/articles/ gscontract.html.

25. Centre for Social Research (CSR). Surrogate motherhood- ethical or commercial 2016. Available from: http://www.womenleadership.in/ Csr/SurrogacyReport.pdf.

26. American Medical Association (AMA) . Opinion 2.18 - Surrogate mothers 2016. Available from: http://www.ama-assn.org/ ama/pub/physician-resources/medical-ethics/code-medicalethics/opinion218.page?

27. Human Fertilisation and Embryology Authority . Surrogacy 2016. Available from: http://www.hfea.gov.uk/501.html\#otherLegislation.

28. Brazier M. Symposium: reference documents on the ethics and laws of human reproduction. Surrogacy: review for the UK health ministers of current arrangements for payments and regulation. Human Reproduction Update. 1997;3(6):623-8. doi:10.1093/humupd/3.6.623.

29. Burrell C, O'Connor H. Surrogate pregnancy: ethical and medicolegal issues in modern obstetrics. Obstetr Gynaecol. 2013;15(2):113-9. doi:10.1111/tog.12010.

30. Queensland Surrogacy Act 2010 . Queensland: State of Queensland Parliament 2016. Available from: www.legislation.qld.gov.au/ LEGISLTN/ACTS/2010/10AC002.pdf.

31. Familylaw . Ukrainian Surrogacy Laws 2016. Available from: http://www.familylaw.com.ua/index.php?option=com_content\& view=article $\&$ id $=68$.
32. National Ethics Committee on Assisted Human Reproduction . Guidelines on IVF surrogacy 2016. Available from: http://www.maia-asso. org/doc/gpa/Traduc_GPA_NZ.pdf.

33. Reilly DR. Surrogate pregnancy: a guide for Canadian prenatal health care providers. Can Med Assoc J. 2007;176(4):483-5. doi: 10.1503/cmaj.060696.

34. INFACT Canada . Your right to breastfeed anywhere, anytime is protected by the Canadian Charter of Rights and Freedoms 2011. Available from: http://infactcanada.ca/Breastfeeding_Rights.htm.

35. Saetnan AR, Oudshoorn N. Bodies of technology: Women's involvement with reproductive medicine. Ohio State University Press; 2000.

36. Dorosti A, Keshavarz SA. In: Textbook of Public Health. Hatami H, Razavi SM, Eftekhar AH, Majlesi F, editors. Tehran: Arjmand Publications; 2012. Infants' feeding.

37. Afshariani R. The role of breastfeeding in the nutrition and development of premature babies. Breastfeeding Q. 2011;11(46):15-6.

38. Schanler RJ, Krebs NF, Mass SB. Breastfeeding handbook for physicians. American Academy of Pediatrics; 2013.

39. World Alliance for Breastfeeding Action (WABA). Happy World Breastfeeding Week 2016. Available from: http://waba.org.my/oldernewssec.htm.

40. Movahed Abtahi M. In: Medical, legal, Islamic jurisprudential, ethical-philosophical, sociological and psychological aspects of surrogacy. Movahed Abtahi M, editor. Tehran: Samt Publications; 2007. Surrogate mother and means of being a mother, a new approach to the Quranic verses and Hadith.

41. Salarzayi AH. Scientific and literary delicacies of Erzae (suckling) Verse in Quran. Meshkat. 2010;108:30-42.

42. Pickthall M. The meaning of the glorious Quran. Marmaduke Pickthall; 2017.

43. Nazari Tavwakkoli S. Child custody in the Islamic jurisprudence. Tehran: Samt Publications; 2006.

44. Tabatabaei SMH. Tafsir Al-Mizan. Qom: Daftar Entesharat Eslami; 1995.

45. Talegani M. Partovi az Quran. Tehran: Sherkat Sahami Enteshar; 1983.

46. Najafi Khomeini MJ. Tafsir Asan. Tehran: Eslamieh Publications;1977.

47. Qureshi SAA. Tafsir Ahsan Al-Hdis. Tehran: Bonyad Beasat; 1998.

48. Tabarsi FBH. Tafsir Javame Al Jame. Mashhad: Bonyad Pajoheshhaye Eslami Astan Qods Razavi; 1998.

49. Hosseini SAHBA. Tafsir Asna Ashari. Tehran: Miqat Publications; 1984.

50. Makarem Shirazi N. Tafsir Nemooneh. Tehran: Dar-ul Kutub alIslamiyyah; 1995.

51. Gonabadi SM. Bayan Al-Saadat fi Maqamat Al-Ebadat. Tehran: Payam Noor University Publications; 1993.

52. Tabarsi FBH. Majma Al-Bayan fi Tafsir Al-Quran. Tehran: Farahani Publications; 1981.

53. Kulayni AJMBY. Al-Kafi. Research by Ali Akbar Ghaffari, Al-Matbah Heidari. Tehran: Dar-ul Kutub Al-Islamiyyah; 1987.

54. Qomi MBABHBB. Man La Yahzar Al-Faqih, Ali Akbar Ghaffari Modaresin. ; 1980 .

55. Al-Tusi MIAH. Tahzib Al-Ahkam. Research by Seyed Hassan AlKhersan, corrected by Mohammad Alakhoun. Tehran: Dar-ul Kutub Al-Islamiyyah; 1986.

56. Aljabay AAZ. Masalek Al-Efham fi Tanqih Sharaye Al-Islam. Qom: Bonyad Maaref Eslami; 1995.

57. Horr Ameli MBH. Vasael Al-Shia Ela Tahsil Masael Al-Shariae. Research by Sheikh Mohammad Al-Razi. Beirut: Dar Ahya Al-Tras Al-Arabi; 1982.

58. Qomi MBABHBB. Uyun Akhbar Al-Reza. Beirut: Moassese Alalami Lematbouat; 1983.

59. Ibn Barraj AQ. Al-Mohazab. Qom: Jamea Al-Modaresin; 1985

60. Hilli bin I. Alsarayer. Qom: Moassese Al-Nashr Eslami; 1990.

61. Hilli Jafar bin H.Al-Mokhtasar Al-Nafea fi Feqhe Al-Imamiya. Cairo: Dar Al-Taqrib; 1989.

62. Hasan ibn AT. Kashf Al-Roumouz fi Sharh Al-Mokhtasar Al-Nafea. Qom: Jame Al-Modaresin; 1987. 
63. Hilli HBY. Qawaid Al-Ahkam fi Maarifat Al-Hilal va Al-Haram. Qom: Moassese Al-Nashr Eslamic; 1992.

64. Bahrani YBA. Al-Hadaeq Al-Nazereah fi Ahkam Al-Etrate Al-Taherah. Research by Mohammad Taqi Al Eyravani. Qom: Jame al-Modaresin; 1988.

65. Isfahani BADM. Kashf Al-lesam va Al-Ebham An Qawaed Al-Ahkam. Qom: Maktabah Ayatollah Al Mareshy Al-Najafi; 1984.

66. Maki AMBJ. Al-Lomaato Al-Dameshqiyeh. Research by Sheikh Ali Alkourani. Qom: Dar Alfekr; 1990.

67. Aljabay AAZA. Al-Roza Al-Bahiyah fi Sharh Al-Lomaato AlDameshqiyeh. Research by Mohammad Kalantar. Qom: Davari Publications; 1999.

68. Muqaddas Ardabili ABM. Majma Al-Faydat Al-Burhan fi Sharhe Ershad Al-Azhan. Qom: Islamic Publication Institute; 1990.

69. Al-Tusi MIAH. Al-Mabsout. Research by Mohammad Bagher AlBehboudi. Qom: Al-Maktabeh Al-Mortazavieh publication; 2008.

70. Mohaqeq Korki ABH. Jamea Al-Maqased. Qom: Moassese Aal Al-Bayt; 1987.

71. Tabatabaei SA. Riyaz Al-Masael. Qom: Moassese Aal Al-Bayt; 1983.

72. Aljabay AAZ. Masalek Al-Efham fi Tanqih Sharaye Al-Islam. Qom: Bonyad Maaref Eslami; 1995.

73. Aljabay AAZA. Al-Roza Al-Bahiyah fi Sharh Al-Lomaato AlDameshqiyeh. Research by Mohammad Kalantar. Qom: Davari Publications; 1999.

74. Hilli JBH. Sharaya Al-Islam fi Masael Al-Halal va Al-Haram. Research of Seyed Sadeq Alshirazi. Tehran: Esteqlal Publication; 1988.

75. UNICEF . Declaration of the Rights of the Child 2016. Available from: http://www.unicef.org/malaysia/1959-Declaration-of-the-Rightsof-the-Child.pdf.

76. Unicef . Convention on the Rights of the Child 2016. Available from: http://digitalcommons.ilr.cornell.edu/cgi/viewcontent.cgi?article= $1007 \&$ context $=$ child .

77. Jahangir M. Civil Law. Tehran: Didar Publication; 2003.

78. Jahangir M. New Penal Code. Tehran: Didar Publication; 2013.

79. Majlis . The statute of breastfeeding promotion and maternal support during breastfeeding period 2016. Available from: http://rc. majlis.ir/fa/law/show/92645.
80. Deputy of Health. Ministry of Health and Medical Education . Of fice of Population, family and school health, office of child health and promotion of breastfeeding. National mandate for breastfeeding from the very early moments of birth 2016. Available from: http //treatment.sbmu.ac.ir/uploads/shire.madar.avale.zendegi_.pdf.

81. Salarzayi $\mathrm{AH}$, Khakpoor H. Jurisprudence analysis of provisions and parts of verse Rezaa (suckling). Jafari Jurisprudence Modern Law J. 2011;1(1):34-56.

82. Rezaniya Moallem MR. Forensic pregnancies in accord with law and Islamic jurisprudence. Qom: Bustane Ketab Press; 2010.

83. Biervliet FP, Maguiness SD, Hay DM, Killick SR, Atkin SL. Induction of lactation in the intended mother of a surrogate pregnancy: case report. Hum Reprod. 2001;16(3):581-3. [PubMed: 11228232].

84. Brinsden PR. Gestational surrogacy. Hum Reprod Update. 2003;9(5):483-91. [PubMed: 14640380].

85. Milanifar AR, Akhondi M, Ardekani ZB, Abdolahzadeh A. Issuing birth certificates and ID cards for newborns following a surrogate birth and the legal and ethical responsibilities of the medical team.J Reprod Infertil. 2008;9(1):82-88.

86. Majlis . Therapeutic Abortion Act 2016. Available from: http://rc. majlis.ir/fa/law/show/97756.

87. Saedi S. In: Medical, legal, Islamic jurisprudential, ethicalphilosophical, sociological and psychological aspects of surrogacy. Saedi S, editor. Tehran: Samt Publications; 2007. Conventional regulations of surrogate mother.

88. Makarem Shirazi N. The Official Website. Rezaa Terms 2011. Available from: http://makarem.ir/main.aspx?typeinfo=2\&lid=0\&mid= $77248 \&$ catid $=20931$.

89. Alavi SMT, Azizi M. An investigation of non-financial rights of in-vitro fertilization child. Islamic Law Jurisprudence J. 2012;3(5):159-13.

90. Tabatabaei SMH. The Principles of Philosophy and the Method of Realism, with an introduction and a footnote by Professor Mortaza Motahari. Qom: Sadra Publications; 1995.

91. Young D. Violating "the Code": breastfeeding, ethics, and choices. Birth. 2001;28(2):77-8. [PubMed: 11380377].

92. Mohaghegh Damad SM. Medical fiqh. Tehran: Hoghughi Publication; 2010. 